Volume 21 Number 1 June 2021. P. 50-68

https://doi.org/10.30603/au.v21i1.2199

\title{
The Contribution of The School of Peace as A Religious Moderation Implementation
}

\author{
Moch. Tolchah ${ }^{1,}$ Kasim Yahiji ${ }^{2}$, Said Subhan Posangi ${ }^{3}$, Nur Ainiyah ${ }^{4}$ \\ ${ }^{1}$ UIN Sunan Ampel Surabaya, 2,3 IAIN Sultan Amai Gorontalo, \\ 4Universitas Negeri Yogyakarta
}

\begin{abstract}
This article focuses on the contribution of the peace school program as one of the implementations of religious moderation strategies in schools. This qualitative research with a phenomenological approach was applied using structured interviews and documentation studies at SMUN Sugihwaras Bojonegoro as a pilot school for the peace school program. The empirical data illustrates the concept of the peace school program, the implementation of the peace school program, and the contribution of the peace school program as a strategy for implementing religious moderation in schools. This study found that the peace school program is one of the programs that significantly contributes to realizing the implementation of religious moderation in schools. This program implements the concept of religious moderation that focuses on inculcating and internalizing the values of tolerance and peace. This program targets the three main pillars of the education process: policies, practices of tolerance and peace in the school environment, and the management of student organizations.
\end{abstract}

Keywords: School of Peace, Religious Moderation, Tolerance

\section{Kontribusi Sekolah Damai Sebagai Wujud Pelaksanaan Moderasi Beragama}

\begin{abstract}
Abstrak
Artikel ini berfokus pada kontribusi program sekolah damai sebagai salah implementasi strategi moderasi beragama di sekolah. Penelitian kualitatif dengan pendekatan fenomenologi ini diterapkan dengan menggunakan metode wawancara terstruktur dan studi dokumentasi di SMUN Sugihwaras Bojonegoro sebagai sekolah percontohan program sekolah damai. Data empiris mengilustrasikan konsep program sekolah damai, pelaksanaan program sekolah damai, dan kontribusi program sekolah damai sebagai strategi pelaksanaan moderasi beragama di sekolah. Penelitian ini menemukan bahwa program sekolah damai merupakan salah satu program yang sangat berkontribusi dalam mewujudkan pelaksanaan moderasi beragama di sekolah. program ini mengimplementasikan konsep moderasi beragama yang terfokus pada penanaman dan internalisasi nilainilai toleransi dan perdamaian. Program ini menyasar pada tiga pilar utama proses pendidikan yang terdiri dari kebijakan, praktek toleransi dan perdamaian di lingkungan sekolah, serta pengelolaan organisasi kesiswaan.
\end{abstract}

Kata Kunci: Sekolah Damai, Moderasi Beragama, Toleransi

Author correspondence

Email: mochtolchah@gmail.com

_Available online at http://journal.iaingorontalo.ac.id/index.php/au/index 


\section{A. Introduction}

Pluralism for the Indonesian nation is a wealth to be proud of. The diversity of races, ethnicities, religions and cultural customs that exist makes the Indonesian people be aware of and uphold mutual respect, respect, and tolerance for existing differences. On the other hand, pluralism is prone to causing friction in society and can lead to conflict. Excessive religious fanaticism and harassing other religious sects or people is one example of the conflicts in today's society resulting from different religious perspectives, but not based on mutual respect and respect. Excessive religious fanaticism can trigger someone to commit violence in order to maintain their beliefs. Even further, this is the forerunner to the growth of radicalism in religion. ${ }^{1}$

The notion of radicalism for the Indonesian people is a threat that can disrupt the integrity of the life of the nation and state. This is because the notion of radicalism can trigger the emergence of intolerance in society. The actions of religious radicalism groups that sometimes use violence, both verbal and non-verbal, are very contrary to our constitution, which guarantees freedom of religion, expression, and belief. Radicalism is a stage or a step before terrorism. In general, terrorists who carry out many destructive actions and suicide bombings have a radical understanding of various things, especially religious matters. ${ }^{2}$

The threat of radicalism and terrorism in Indonesia is real and even increasing. 3 Massively, radicalism groups propagate the public through various means, including through social media, ${ }^{4}$ educational institutions, 5

\footnotetext{
1 Ali Muhtarom et al., Islam Agama Cinta Damai: Upaya Menepis Radikalisme Beragama (Pilar Nusantara, 2019), 19.

2 Ahmad Fuad Fanani, "Fenomena Radikalisme Di Kalangan Kaum Muda," Jurnal Maarif 8, no. 1 (2013): 5 .

${ }^{3}$ Afadlal, Islam dan radikalisme di Indonesia (Yayasan Obor Indonesia, 2005), 5.

4 M Nanda Fanindy and Siti Mupida, "Pergeseran Literasi Pada Generasi Milenial Akibat Penyebaran Radikalisme di Media Sosial," Millah: Jurnal Studi Agama 20, no. 2 (2021): 195-222.

${ }^{5}$ Abdul Azis Muslim et al., Menjaga Benteng Kebinekaan Di Sekolah: Studi Kebijakan OSIS Di Kota Padang, Kab. Cirebon, Kab. Sukabumi, Kota Surakarta, Kota Denpasar, Dan Kota Tomohon., 1st ed. (Jakarta: MAARIF Institute for Culture and Humanity, 2018), 5.
} 
The Contribution of The School of Peace as A Religious Moderation Implementation

religious study institutions, ${ }^{6}$ And socio-political institutions. ${ }^{7}$ Their targets are not only adults but even more concerning teenagers and children.

Schools or educational institutions are one of the media that has the potential to develop radicalism. School is an open space for the dissemination of any understanding. Because the school is too loose, religious radicalism groups take advantage of this open space to campaign for their understanding and expand their network actively. Research by the Maarif Institute (2011), Setara Institute (2015), and the Wahid Foundation (2016) shows that radical groups have massively penetrated radical views among the younger generation through educational institutions. ${ }^{8}$

The seeds for the development of radicalism have been evident in educational institutions. Research conducted by the Institute for Islamic Studies and Education in 2014 has released 34\% of young people among high school students agreeing to acts of jihad with violence carried out by radical groups such as Jamaah Islamiyah. A survey conducted by the Wahid Foundation (2016) stated that around 60 percent of the 1,626 Islamic Spiritual (Rohani Islam - ROHIS) activists in high schools in Indonesia are willing to go to conflict areas if the opportunity arises. Meanwhile, currently, if there is an invitation or call for jihad in the form of fighting to defend Muslims who are oppressed elsewhere, $73.3 \%$ of respondents say they are willing. These data indicate significantly if indications of radicalism have influenced the way students think to become intolerant of followers of other religions or people outside their group.

Various methods are used to spread the notion of radicalism among students in the name of religious and political interests. For example, the case of student mobilization in demonstrations against Ahok's leadership by

\footnotetext{
${ }^{6}$ Edi Susanto, "Kemungkinan Munculnya Paham Islam Radikal di 'Pondok Pesantren,'” TADRIS: Jurnal Pendidikan Islam 2, no. 1 (January 5, 2007), https://doi.org/10.19105/tjpi.v2i1.205.

${ }^{7}$ Anzar Abdullah, "GERAKAN RADIKALISME DALAM ISLAM: PERSPEKTIF HISTORIS," ADDIN 10, no. 1 (February 1, 2016): 9, https://doi.org/10.21043/addin.v10i1.1127.

8 Muslim et al., Menjaga Benteng Kebinekaan Di Sekolah: Studi Kebijakan OSIS Di Kota Padang, Kab. Cirebon, Kab. Sukabumi, Kota Surakarta, Kota Denpasar, Dan Kota Tomohon., 6.
} 
bringing up the issue of blasphemy in $2016^{9}$, the ban on flag ceremonies in several schools in Jambi occurred in 2017 because students should only respect their God. ${ }^{10}$ These cases show that the spread of radicalism has been packaged neatly by riding various interests, whether political, religious, or social.

There are three main doors for how radical understanding and intolerance penetrate the school environment; First, extracurricular activities. Second, the teacher's role in the teaching and learning process. Third, through weak school policies in controlling the entry of radicalism in schools. If you look at the data described above, the development of radicalism in the school environment is getting stronger and requires special attention. Therefore, a strategy for implementing religious moderation in schools is needed because the classroom is a strategic place for the cultivation of national values, multiculturalism, tolerance, and a more peaceful messenger of religion. Instilling the values of moderation in religion in schools is one of the efforts in creating a peaceful life for the Indonesian people in a variety of differences. ${ }^{11}$ Several attempts have been made to realize the values of religious moderation in educational institutions, one of which is the peace school program initiated in 2017.

The peace school program initiated by the Wahid Foundation and in collaboration with the Association of Indonesian Islamic Religious Education Teachers (Asosiasi Guru Pendidikan Agama Islam Indonesia - AGPAII) is one of the strategies in implementing the concept of religious moderation in schools. This program seeks to create a school environment that can shape students to absorb and apply the values of harmony, inclusivism, harmony, and peace. The peace school program is one of the efforts made in responding to the rise of

\footnotetext{
9 Merdeka.com, "Polemik Al-Maidah, ratusan pelajar diajak guru demo Ahok," 2017, https://www.vidio.com/embed/2213842-kalau-pak-ganjar-pranowo-jadipresiden?autoplay=true\&embed_position=nativeembed\&live_chat=false\&mute=true\&player_only=true\&sticky=false.

10 Liputan6.com, "Larang Siswa Upacara Bendera, Izin Sekolah Terancam Dicabut," liputan6.com, December 10, 2017, https://www.liputan6.com/regional/read/3190592/larang-siswa-upacarabendera-izin-sekolah-terancam-dicabut.

11 Edy Sutrisno, “Aktualisasi Moderasi Beragama Di Lembaga Pendidikan,” Jurnal Bimas Islam 12, no. 2 (2019): 342.
} 
terrorism cases in Indonesia lately by implementing and internalizing the values of tolerance and peace in the school environment.

This research is a descriptive study conducted in a pilot school that implements the peace school program, namely SMAN Sugihwaras Bojonegoro. This research aims to (1) how is the concept of the peace school program, (2) how is the implementation of the peace school program? Furthermore, (3) how is the contribution of the peace school program as a strategy for implementing religious moderation in schools.

\section{B. Peace School Program}

The Peace School Program is an initiative of the Wahid Foundation in collaboration with the Association of Indonesian Islamic Religious Education Teachers (Asosiasi Guru Pendidikan Agama Islam Indonesia - AGPAII) against the widespread cases of intolerance and radicalization in Indonesia among the general public and even in educational institutions which the government and the community management. Schools have become strategic targets for the spread of radicalism and intolerance, this is evidenced by research conducted by the Wahid Foundation in 2016 on 1,626 students of Islamic Spirituality (Rohani Islam - ROHIS) activists, there are at least 60 percent who say they are willing to go jihad to conflict areas such as Syria if given a chance.

The data above is the background for establishing the peace school program, intending to create students who are more moderate in understanding their religion and being tolerant of other religions. This program is structured creatively and systematically, following the characteristics of students who are in their development period as teenagers full of creativity. This program is packaged to motivate and instill values of tolerance in students systematically and sustainably.

The program, which was initiated in 2017, serves as a guide for schools to create a school environment that can shape students to absorb and apply 
the values of harmony, inclusivism, harmony, and peace. ${ }^{12}$ This program has been implemented in 60 schools at the SMA and SMK levels in several provinces: West Java, DKI Jakarta, Central Java, and East Java. The peace school program does not make a special curriculum. However, it adapts it to the existing institutional curriculum in each school, based on three main pillars: policy, the practice of tolerance and peace, and the management of student organizations. ${ }^{13}$

The first aspect, the policy pillar, aims to foster a peaceful school culture through strategic policies that a school has owned. It intends to strengthen the implementation of Pancasila values in school life, one of which is to respect all school members without discrimination caused by religion, religious views, beliefs, ethnicity, understanding, social status, economy, background, and strengthen interactions between citizens. Safe, comfortable and harmonious school. 14

The focus of the pillars of the Peace School policy includes five things including: (1) policies that cover the roles and functions of the implementing team and the development of the School of Peace, (2) policies that contain the integration of the School of Peace Program in school policies, (3) policies containing school environment management related to schools. Peace, (4) The policy contains the management of learning activities in the classroom that strengthens the Peace School Program, (5) the policy contains an early detection system for intolerance and radicalism. ${ }^{15}$

The second aspect is the pillar of strengthening the practice of tolerance and peace in schools and classrooms. This aspect relates to efforts to cultivate the values of tolerance and peace through practice in school and classroom life. The concrete form of implementation in this aspect is planning and managing lessons that reflect the values of peace and tolerance. Every teacher is required to carry out the teaching and learning process that emphasizes the importance

\footnotetext{
12 Mahnan Marbawi et al., Mencipta Generasi Penjaga Kebhinekaan "Panduan Sekolah Damai, Konsep Dan Indikator," 1st ed. (Jakarta: Wahid Foundation, 2019).

13 Marbawi et al.

14 Marbawi et al., 27.

15 Marbawi et al., 29.
} 
of tolerance, caring, and inclusive values. For example, Religious Education teachers take an active role in strengthening classroom culture, among others, in preparing learning materials that instill respect for differences and facilitate open and critical religious values. ${ }^{16}$

The pillars of strengthening the practice of tolerance and peace are focused on two essential environments: (1) the school environment, covering the entire area belonging to the school to the environment around the school. Several programs implemented in this environment are cultivating open interaction in the school environment between teachers, students, and parents of students with different religious backgrounds, beliefs, ethnicities, social status, and others and practicing the values of tolerance and togetherness in public spaces, for example creating a shared garden that reflects the values of tolerance and togetherness or a shared learning space that can be accessed by all students-promoting messages of peace in the school environment, for example promoting quotes for messages of peace and tolerance, information about peace school programs, and activities in schools through signage or social media. (2) the classroom environment, cultivating the values of tolerance and peace in the classroom environment targeting classroom management, is managed directly by the teacher and focuses on two activities: classroom management and learning methods. ${ }^{17}$

The third aspect relates to the program's pillars for improving the management of student organizations and human resource capacities that promote and practice peace and tolerance. Strengthening the program is carried out by developing more open interactions between students, respecting differences in religion, understanding, belief, discourse, opinions, groups, socio-economics, and strengthening inclusive values. Activities are carried out collaboratively, participative, and creatively. Programs are synergized with the roles of principals, teachers, and the school community. The efforts made in this aspect are implementing and internalizing the values

\footnotetext{
16 Marbawi et al., 33-38

17 Marbawi Et Al., Mencipta Generasi Penjaga Kebhinekaan "Panduan Sekolah Damai, Konsep Dan Indikator," 34-39.
} 
of tolerance and peace in the organization and management of student organizations. ${ }^{18}$

The three pillars of the peace school program above serve as instructions on how, what, and who is the target for implementing the peace school program in the school environment. The three pillars also indicate that all stakeholders determine the school's success of the peace school program. This program targets teachers and students, but all components in the school must synergize and be consistent in supporting the implementation of the peace school program.

\section{Implementation of the peace school program in schools}

The SMAN 1 Sugihwaras Bojonegoro is one of the pilot schools for the peace school program. As with the principle of the peace school program, this school has special activities to create a peaceful school adapted to the culture and characteristics of its environment. Several activities at SMAN 1 Sugihwaras Bojonegoro that implement the peace school program are described by dividing them into three main pillars as follows:

\section{Policy pillar}

As one of the pilot schools for the peace school program, SMAN 1 Sugihwaras Bojonegoro implemented a policy to encourage implementing the peace school program by making a Decree (SK) for the formation of the Peace School Task Force. This task force consists of teachers and students. They are at the forefront of providing examples of peaceful and tolerant behavior in the school environment, including being directly involved in resolving conflicts in schools. Teachers, in particular, have a dual role as coaches for the students of the task force members. They are responsible for guiding and supervising the activities of these students, especially concerning the implementation of the School of Peace practice. For example, if there is a dispute between students, the teachers will ask and guide the

18 Marbawi et al., 42-43. 
students, members of the Peace School Task Force, to find out the problem and mediate. Thus, the approach to resolving conflicts between students are no longer limited to giving punishments but building solidity and brotherhood. 19

The policy pillar is the legal umbrella for implementing the peace school program in schools and is the opening door for the implementation of the program. The policy pillar also reflects the commitment of all components in the school to work together in synergy to establish themselves in the success of the implementation of the peace school program. This joint commitment is needed to become a trigger for the success of the peace school program to achieve its goals.

\section{Pillars of the practice of tolerance and peace in the school environment}

One of the crucial things in implementing the peace school program is to practice the principles of the peace school program, which is about inculcating and internalizing the values of tolerance and peace in school life. SMAN 1 Sugihwaras Bojonegoro has several programs that encourage the realization of the values of tolerance and peace in school life, some of which are cultural performances that are held regularly every year. This performance aims to make students more familiar with the diversity of Indonesian culture from Sabang to Merauke. Musical extracurriculars and hadrah arts are also ways that SMAN 1 Sugihwaras Bojonegoro introduces and loves cultural diversity. ${ }^{20}$

Another program implemented at SMAN 1 Sugihwaras is to cultivate a culture of life in diversity. One of them is providing space for religious practice for students with any religious background before starting teaching and learning activities in class. To Muslim students they read the Koran. For non-Muslims, read the holy books of their respective religions. This activity

\footnotetext{
19 Ahsan Ridhoi, Sekolah Penjaga Kebhinekaan "Cerita Baik Program Sekolah Damai Wahid Foundation,"1st ed. (Jakarta: Wahid Foundation, 2019).

${ }^{20}$ Ridhoi.
} 
is monitored and guided by the teacher directly. This program aims so that students can better understand the holy books of their respective religions and get used to seeing differences in the practice of worshiping other religions. In this way, indirectly, it is hoped to develop an attitude of tolerance in religion. ${ }^{21}$

The digital sign above the entrance gate that reads "Welcome to the School of Peace" confirms that SMAN 1 Sugihwaras declares itself as a pilot school that is committed to implementing the basic principles of the peace school program, namely instilling and internalizing the values of tolerance and peace in the environment. School. This affirmation was also carried out by posting slogans or messages of peaceful and tolerant living in classrooms and wall magazines. These activities aim to promote peace and tolerance through written messages. ${ }^{22}$

The goal of the peace school program is to instill the values of tolerance and peace in the school environment. The inculcation of these values can be done by conveying them at the level of knowledge and touching the affective and psychomotor aspects as the nature of educational goals. Therefore, it is necessary to have actual practices in the school environment that reflect the values of tolerance and peace. This can be realized by assembling all activities in schools, classroom learning, and extracurricular activities, based on the inculcation of the values of tolerance and peace and arranging the environment and school to become a conducive driving force.

\section{Pillars of student organization management}

Cultivating openness and cooperation among students of different religions is one of the commitments that continue to be promoted at SMAN 1 Sugihwaras through student organizations. Several student organization activity programs aim to develop mutual tolerance, including visits to houses of worship of various religions. Doing social services promote peace

21 Ridhoi.

22 Ridhoi. 
because, in principle, peace is not just a matter of etiquette and mutual respect, but more than that is an attitude of caring and being willing to sacrifice for others. ${ }^{23}$

As the data previously stated, extracurricular organizations, such as the ROHIS, become one of the most strategic targets in spreading radicalism. Based on these data, student organizations should be an essential target in the implementation of peace schools. The school, especially the teacher, must be a supervisor and a coach in every student organization. Schools need to select who is involved, as well as what programs exist in each student organization. This needs to be done so that schools are no longer fertile ground for the development of radicalism.

Based on the description of the data above, SMAN 1 Sugihwaras consistently carries out the pillars of the peace school program well. Students and existing stakeholders synergize with each other to create a peaceful school in their school environment. This shared commitment is the key to success in achieving the goals of the peace school, namely instilling and internalizing the values of tolerance and peace in everyday life in the school environment. The hope in the future is that they can voice and spread the values of tolerance and peace in a society that will impact a peaceful life in diversity for the Indonesian nation.

\section{Contribution of the Peace School Program as a Strategy for Implementing} Religious Moderation in Schools

Schools of peace in the world were created to overcome various acts of violence as a result of conflicts in society against the backdrop of cultural, religious, and racial diversity. Schools are a powerful space for building new meanings about what peace is and how people deal with it, exploring intercultural ideas as needed, developing capacities, and promoting positive coexistence. In this regard, the goals of Peace Education include teaching about

${ }^{23}$ Ridhoi. 
the challenges of seeking and achieving peaceful relations, developing nonviolent skills, and improving attitudes towards peace. ${ }^{24}$

The United Nations (UN), through the United Nations Children's Fund (UNICEF), defines peace education as "a process of promoting the knowledge, skills, behaviors, and values necessary to bring about attitude change that enables children, youth and youth to prevent conflict and violence, both direct and structural; to find non-violent solutions to conflict; and to create favorable conditions for peace, whether personal, interpersonal, group, national or international level. ${ }^{25}$

Like peace schools globally, in Indonesia, several government and nongovernment institutions have taken the initiative to implement peace education. In general, the initiative to develop peace education in Indonesia is in response to the current situation of socio-religious life, which tends to be less tolerant, permissive to violence, and discriminates against minority groups. Many things indicate that intolerance in Indonesia has become the new normal that occurs in everyday life, including in schools. ${ }^{26}$ Conservative education that further echoes a sense of identity within the group by emphasizing differences can create 'religio-centric' students who can only see truth among their group and error in others. ${ }^{27}$

Peace education is widely recognized as an educational model that aims to develop peace or respond to various conflicts in society, starting from the school environment. However, the concept of peace education needs to be adapted to the local community's needs because, in essence, no one model is most suitable for all societies. ${ }^{28}$ The peace school program initiated by the Wahid Foundation is one of the peace education programs formed according to the community's needs.

\footnotetext{
${ }^{24}$ Cabedo-Mas, 77.

${ }^{25}$ Susan Fountain, "Peace Education in UNICEF" (Working Paper of UNICEF, New York, 1999), http://www.unicef.org/education/files/PeaceEducation.pdf. 26 Sandra Hamid, "Normalising Intolerance: Elections, Religion and Everyday Life in Indonesia," Melbourne Law School, June 26, 2018, https://law.unimelb.edu.au/centres/cilis/research/publications/cilis-policy-papers/normalisingintolerance-elections,-religion-and-everyday-life-in-indonesia. 27 Hamid, 22.

${ }^{28}$ McGlynn, Peace Education in Conflict and Post-Conflict Societies, 1.
} 
As one of the models of the peace school, the peace school program has distinctive main principles following the basic foundations and characteristics of the Indonesian nation. These principles include:

1. Based on Pancasila and the 1945 Constitution as the ideal principles that govern the state's life.

2. Upholding human rights, where everyone has the right to life, religion, expression, and politics.

3. Respect for Diversity. Diversity or diversity is a fact of life that is almost impossible to avoid. This diversity appears in various levels ranging from individuals, groups, ethnicities, beliefs, birth origin, and gender. As a fact of life, there is no other way to respect diversity in social and national life becomes the primary prerequisite.

4. The nine central values of Gus Dur. These values were formulated by Gus Dur together with national figures and resulted in universal values, in line with the principles of human rights and not contradicting the teachings of religions in Indonesia, especially Islam. The nine values include monotheism, humanity, justice, equality, liberation, simplicity, brotherhood, chivalry, and local wisdom. ${ }^{29}$

Based on these principles, the peace school program develops learning objectives on inculcating and internalizing the values of tolerance and peace in the school environment. The peace school program aims to create a school environment that allows all components to become ambassadors of peace outside. The school environment does mean the boundaries of the physical school building and an imaginary space supported by policies that encourage the formation of a culture of peace. Key concepts in peace education will be the basis for developing the learning process in schools. So that all components in schools consisting of principals, teachers, students, and other school residents

${ }^{29}$ Marbawi et al., Mencipta Generasi Penjaga Kebhinekaan "Panduan Sekolah Damai, Konsep Dan Indikator," 25. 
are expected to be role models and ambassadors for peace both at school and outside school. ${ }^{30}$

Based on the description of the peace school program above, it can be concluded that the objectives of the peace school program are in harmony with the concept of religious moderation in Islam (wasathiyah) in Indonesia. Both underlined the goal of establishing tolerance and harmony in religious differences. Moderation in Islam refers to the word wasathiyah. This word means middle, justice, or the best. In the concept of wasathiyah, fair means balance. If it is ba:"مُ وسطة"he fragment of the word ummatan wasatan Al-Baqarah:1 43), it is interpreted as Allah created Muslims as "ummatan wasatan," which implies that even though they are different, they can walk side by side in one broad road and lead them to the pleasure of Allah. S.W.T. Wasathiyah is defined as people who can go hand in hand with different groups in a broad and straight path. Differences in teachings no longer affect them because they all agree on the principles of their respective religions. The principle of religious moderation in the view of Islam can be broken down into three types, namely the principle of justice (al 'adalah), balance (al tawazun), and tolerance (al tasamuh). ${ }^{31}$

Religious moderation is an attitude in religion that is balanced between the practice of one's religion (exclusive) and respect for the religious practices of other people of different religions (inclusive). Religious moderation in the context of the multicultural Indonesian nation is the key to creating tolerance and harmony, maintaining civilization, and creating peace at the local, national, and global levels because, in this way, the diversity of religions that exist will not be a barrier for everyone with different religions. To respect each other, accept differences, and live peacefully in harmony. 32 This respect and appreciation are not due to a particular interest but because of sincerity, honesty, and concern for one another. Religious moderation requires an

\footnotetext{
30 Marbawi et al., 19.

31 Dudung Abdul Rohman, Moderasi Beragama Dalam Bingkai Keislaman Di Indonesia (Lekkas, 2021), 17.

32 Indonesia and Indonesia, eds., Moderasi beragama, Cetakan pertama (Jakarta: Badan Litbang dan Diklat, Kementerian Agama RI, 2019), 18.
} 
attitude of mutual openness with dialogue and constructive relationships between religious communities. The practice of religious moderation makes religious values real and meaningful. ${ }^{33}$

Religious moderation is indicated by combining text and context, namely religious thought that does not solely rely on the truth of religious texts and imposes the submission of new realities and contexts to the truth of the text but can dialogue between the two dynamically. ${ }^{34}$ There are four indicators of religious moderation that must continue to campaign, namely national commitment, tolerance, anti-violence, and being accommodating to local culture. ${ }^{35}$

Religious moderation in Indonesia is one of the programs launched by the government to prevent and straighten religious ideas that are seen as extreme. Today, many acts of violence in Indonesia are motivated by religious motives, such as the destruction of houses of worship, insults to religious symbols, insults to religious leaders, and various other conflicts in society with religious motives. ${ }^{36}$ As a multicultural nation prone to various frictions in society, such as conflicts motivated by religious issues, religious moderation for the Indonesian people is a must and will be a balancer in existing differences.

The government has planned various strategies for implementing religious moderation. Through the ministry of religion, the implementation of religious moderation has been stated in the vision and mission of the 20202024 Strategic Plan, which reads: "The realization of an Indonesian Society that is Religiously Obedient, Moderate, Intelligent, and Superior." Furthermore, one of the strategic programs to realize this vision is implementing religious

\footnotetext{
33 Th Sumartana, Pluralisme, Konflik Dan Pendidikan Agama, Yogyakarta, Pustaka Pelajar, 2001., 1st ed. (Yogyakarta: Pustaka Pelajar, 2001), 12.

${ }^{34}$ Indonesia and Indonesia, Moderasi beragama.

35 Kementrian Agama, "Sekjen: Pemda \& Kemenag Perlu Sinergi Perkuat Moderasi Beragama Di Sekolah," accessed June 27, 2020, https://kemenag.go.id/read/sekjen-pemda-kemenag-perlusinergi-perkuat-moderasi-beragama-di-sekolah-gm90x.

${ }^{36}$ Rohman, MODERASI BERAGAMA Dalam Bingkai Keislaman Di Indonesia, 1.
} 
Moch. Tolchah, Kasim Yahiji, Said Subhan Posangi, Nur Ainiyah

moderation in educational institutions ranging from PAUD to higher education. ${ }^{37}$

Educational institutions must be the leading force in the implementation and strengthening of religious moderation, among others, by strengthening the curriculum and teaching and learning materials with the perspective of religious moderation, cultivating interactions that reflect the values of religious moderation in the school environment, and strengthening policies as a legal umbrella for the implementation of the religious moderation program. Education must be a formal object in campaigning and transferring peace values. Educational institutions must dare to build a harmonious and tolerant social order. ${ }^{38}$

The schoolroom is a breeding ground for national ideas, instilling the values of multiculturalism, bringing religious messages more peacefully, and spreading the love for humanity. This is manifested in a curriculum that is oriented towards religious moderation. In line with this, the Peace School program has a substantial contribution in realizing the concept of religious moderation in Indonesia. ${ }^{39}$ The peace school program is a very strategic tool in instilling the values of tolerance and peace. Furthermore, the peace school program is one of the deradicalization efforts for children and adolescents by cultivating the values of religious moderation, which are reflected in all activities in the school environment.

The peace school program does not create a particular curriculum. However, it harmonizes the existing curriculum in each school with the principles of the peace school program, namely by implementing the planting and internalization of the values of tolerance and peace in every activity in the school. So that each school has a different way and approach in implementing the peace school program tailored to the needs and culture of each school, the peace school program is planned systematically and sustainably with the aim that the practice of tolerance and peace that is instilled does not only occur in

\footnotetext{
37 Indonesia and Indonesia, Moderasi beragama, 140.

38 Georger s Counts, Menggugat Pendidikan, Beranikah Sekolah Membangun Tatanan Sosial Yang Baru? (Yogyakarta: Pustaka Pelajar, 2015), 355.

39 Sutrisno, "Aktualisasi Moderasi Beragama Di Lembaga Pendidikan," 342.
} 
the school environment but can spread widely in the community through examples and campaigns carried out by students and all components in schools as "peace ambassadors of the community." peace school program.

\section{E. Conclusion}

Religious moderation is one of the mainstreamed programs by the government as a solution in warding off the recent conflicts in Indonesia caused by a radical understanding of religion. Religious moderation in the Indonesian concept focuses on the meaning of tolerance and harmony in different religions' lives. Multicultural culture is a gift. Therefore religious moderation for the Indonesian people is a must to create peace in existing differences.

One of the critical targets for the spread of radicalism is children and adolescents. Therefore educational institutions are very strategic media to instill the values of religious moderation. The Peace School Program is one of the educational programs that aim to implement religious moderation in the school environment. This program is committed to fostering religious moderation by cultivating and internalizing the values of tolerance and peace. This program makes the practice of tolerance and peace a school culture that targets all existing stakeholders. The values of tolerance and peace are not only understanding but also reach the affective and psychomotor domains as well as the nature of educational goals so that this program is directed at the three main pillars of the education process, namely the pillars of policy, the practice of tolerance and peace in the school environment, and the management of student organizations. 


\section{References}

Abdullah, Anzar. "GERAKAN RADIKALISME DALAM ISLAM: PERSPEKTIF HISTORIS.” ADDIN 10, no. 1 (February 1, 2016): 1. https://doi.org/10.21043/addin.v10i1.1127.

Afadlal. Islam dan radikalisme di Indonesia. Yayasan Obor Indonesia, 2005.

Agama, Kementrian. "Sekjen: Pemda \& Kemenag Perlu Sinergi Perkuat Moderasi Beragama Di Sekolah." Accessed June 27, 2020. https://kemenag.go.id/read/sekjen-pemda-kemenag-perlu-sinergiperkuat-moderasi-beragama-di-sekolah-gm90x.

Cabedo-Mas, Alberto. "Challenges and Perspectives of Peace Education in Schools: The Role of Music," no. 1 (2015): 11.

Counts, Georger s. Menggugat Pendidikan, Beranikah Sekolah Membangun Tatanan Sosial Yang Baru? Yogyakarta: Pustaka Pelajar, 2015.

Djafar, : Alamsyah M. : : Ragam Kebijakan Cegah Ekstremisme Di Sekolah. Jakarta: Wahid Foundation, 2020.

Fanani, Ahmad Fuad. "Fenomena Radikalisme Di Kalangan Kaum Muda." Jurnal Maarif 8, no. 1 (2013): 4-13.

Fanindy, M Nanda, and Siti Mupida. "Pergeseran Literasi Pada Generasi Milenial Akibat Penyebaran Radikalisme Di Media Sosial." Millah: Jurnal Studi Agama 20, no. 2 (2021): 195-222.

Fountain, Susan. "Peace Education in UNICEF." Presented at the Working Paper of UNICEF, New York, 1999. http://www.unicef.org/education/files/PeaceEducation.pdf.

Hamid, Sandra. "Normalising Intolerance: Elections, Religion and Everyday Life in Indonesia." Melbourne Law School, June 26, 2018. https://law.unimelb.edu.au/centres/cilis/research/publications/cilispolicy-papers/normalising-intolerance-elections,-religion-and-everydaylife-in-indonesia.

Indonesia, and Indonesia, eds. Moderasi beragama. Cetakan pertama. Jakarta: Badan Litbang dan Diklat, Kementerian Agama RI, 2019.

Liputan6.com. "Larang Siswa Upacara Bendera, Izin Sekolah Terancam Dicabut." liputan6.com, December 10, 2017. https://www.liputan6.com/regional/read/3190592/larang-siswa-upacarabendera-izin-sekolah-terancam-dicabut. 
Marbawi, Mahnan, Setyo Iswoyo, Husni Mubarok, Alamsyah M Dja'far, and Aprida Sondang. Mencipta Generasi Penjaga Kebhinekaan "Panduan Sekolah Damai, Konsep Dan Indikator." 1st ed. Jakarta: Wahid Foundation, 2019.

McGlynn, Claire, ed. Peace Education in Conflict and Post-Conflict Societies: Comparative Perspectives. 1st ed. New York: Palgrave Macmillan, 2009.

Merdeka.com. "Polemik Al-Maidah, ratusan pelajar diajak guru demo Ahok," 2017. https://www.vidio.com/embed/2213842-kalau-pak-ganjar-pranowo-jadipresiden?autoplay=true\&embed_position=nativeembed\&live_chat=false\&mute=true\&player_only=true\&sticky=false.

Muhtarom, Ali, Dr H. Abdul Karim Karim, Abdul M.Ag, Jamal Ma'mur Asmani, and Yusuf Hasyim. Islam Agama Cinta Damai: Upaya Menepis Radikalisme Beragama. Pilar Nusantara, 2019.

Muslim, Abdul Azis, Anis F Fuadah, Benni Setiawan, M Hafidz Ghazali, Nikmatullah Syarif, and Zuhri, Saefuddin. Menjaga Benteng Kebinekaan Di Sekolah: Studi Kebijakan OSIS Di Kota Padang, Kab. Cirebon, Kab. Sukabumi, Kota Surakarta, Kota Denpasar, Dan Kota Tomohon. 1st ed. Jakarta: MAARIF Institute for Culture and Humanity, 2018.

Ridhoi, Ahsan. Sekolah Penjaga Kebhinekaan "Cerita Baik Program Sekolah Damai Wahid Foundation." 1st ed. Jakarta: Wahid Foundation, 2019.

Rohman, Dudung Abdul. Moderasi Beragama Dalam Bingkai Keislaman Di Indonesia. Lekkas, 2021.

Shihab, M. Quraish. Wasathiyyah Wawasan Islam tentang Moderasi Beragama. Lentera Hati Group, 2019.

Sumartana, Th. Pluralisme, Konflik Dan Pendidikan Agama, Yogyakarta, Pustaka Pelajar, 2001. 1st ed. Yogyakarta: Pustaka Pelajar, 2001.

Supriyatno, Helmi. "Membumikan Moderasi Beragama Di Lembaga Pendidikan." Harian Bhirawa Online (blog). Accessed June 27, 2020. https://www.harianbhirawa.co.id/membumikan-moderasi-beragama-dilembaga-pendidikan/.

Susanto, Edi. "KEMUNGKINAN MUNCULNYA PAHAM ISLAM RADIKAL DI 'PONDOK PESANTREN."' TADRIS: Jurnal Pendidikan Islam 2, no. 1 (January 5, 2007). https://doi.org/10.19105/tjpi.v2i1.205.

Sutrisno, Edy. “Aktualisasi Moderasi Beragama Di Lembaga Pendidikan.” Jurnal Bimas Islam 12, no. 2 (2019): 323-48. 